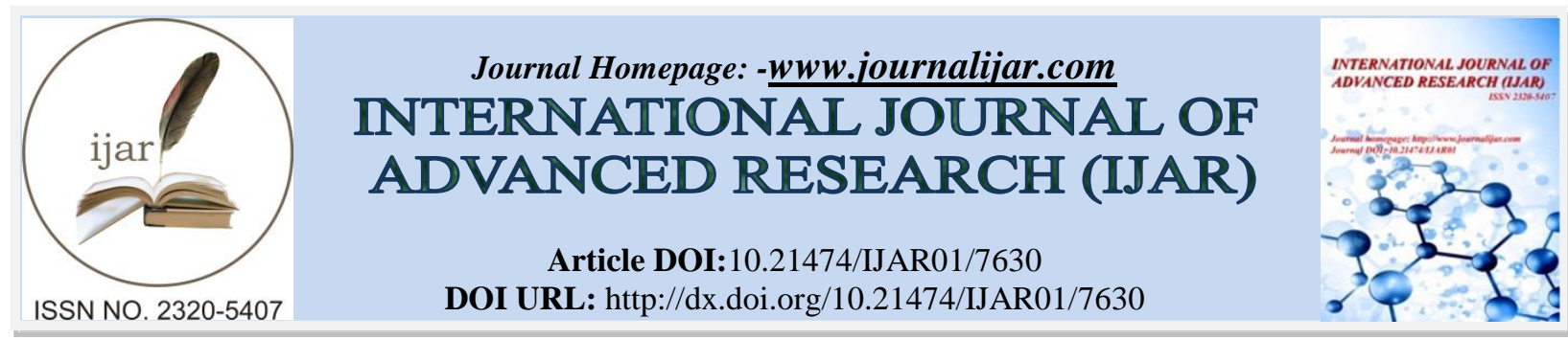

RESEARCH ARTICLE

\title{
EVALUATION OF BIOSORPTION POTENTIAL AND PRODUCTION OF BIOCOMPOST AND BIOGAS FROM METAL ACCUMULATED SEAWEEDS
}

Krishna Y. Pandya ${ }^{1,2}$, Rinku V. Patel ${ }^{1,2}$, Bhavesh Patel ${ }^{3}$, Nayana Brahmbhatt ${ }^{1 *}$

1. Departmet of Biology, V. P. \& R.P.T.P. Science College, Sardar Patel University, Vallabh vidhyanagar-388120, Gujarat, India.

2. Sophasticated Instrumentation Centre for Applied Research and Testing, Vallabh vidhyanagar-388120, Gujarat, India.

3. Principal, V.P. \& R.P.T.P. Science College, Sardar Patel University, Vallabh Vidyanagar-388120, Gujarat, India.

\section{Manuscript Info}

…........................

Manuscript History

Received: 24 June 2018

Final Accepted: 26 July 2018

Published: August 2018

Keywords:-

Accumulated algae, Biocompost, Biogas, Biosorption, Germination,

Heavy metal

\section{Abstract}

This paper investigates the potential of accumulated seaweeds used in biosorption of metals from effluents. The order of biosorption found in Kappaphycus alvarezii > Ulva lactuca > Caulerpa racemosa. The biosorption of $\mathrm{Cr}, \mathrm{Ni} \mathrm{Cu}$ removal received in Kappaphycus alvarezii, Ulva lactuca, Caulerpa racemosa found as $68.71 \%$ (E1), $90.22 \%$ (E1), $81.53 \%$ (E4); $62.2 \%$ (E6), $35.63 \%$ (E1) and $70.35 \%(\mathrm{E} 4)$ and $20.23 \%$ (E1), $28.84 \%$ (E1) and $42.91 \%$ (E6) respectively. After treatment accumulated seaweeds applied to evaluate biocompost, biogas and biofertilizing potential. The algal compost analysis values were nearer to Indian Govt. specifications, they observed maximum for total organic carbon in Caulerpa racemosa (16.87\%), total phosphate in Ulva lactuca $(0.36 \%)$, total potassium and total nitrogen in Ulva lactuca $(0.72 \%)$ and Kappaphycus alvarezii $(0.9 \%)$ respectively. The $\mathrm{C} / \mathrm{N}$ ratio was found maximum in Caulerpa racemosa (28.11). The biofertilizing potential was studied by applying the compost on Triticum aestivum and Vigna radiata seeds which received effective germination and pigment content in both the plants as compare to control which shows good level of pigment content in plants. The maximum biogas was found in Caulerpa racemosa, Kappaphycus alvarezii and Ulva lactuca as $23.90 \%, 21.39 \%$ and $17.29 \%$.

Copy Right, IJAR, 2018,. All rights reserved.

\section{Introduction:-}

Biodegradation of pollutants and heavy metals are most promising treatment technology for environmental pollution control, it is the economical way and naturally degrades the pollutants and reduces the environmental toxins thus it can be used in much lower cost as compare to other treatment technology[8]. An alga shows potential capability for the biosorption and biodegradation of industrial contaminated waste. The accumulation of heavy metals inside the cells of biomass of biological materials such as algae, fern, fungi, yeast observed very high [31][24][14][42]. The macro-algae such as Caulerpa racemosa, Ulva lactuca and Kappaphycus alvarezii used in the biodegradation of dye and metal containing industrial waste water, it was studied in the authors previous research papers [26][27][28][29].

Corresponding Author:- Nayana brahmbhatt.

Address:-Departmet of Biology, V. P. \& R.P.T.P Science College, Sardar Patel University, Vallabh vidhyanagar-388120, Gujarat, India. 
Many scientists have reported potential of algae in heavy metal sorption and biodegradation[2][16][35]. Thus, it establishes economically cheapest method for the waste treatment as it does not require high maintenance or power consumption and generates no secondary waste.

The objective of the present study is re-using of the seaweeds which are highly accumulated with dye component and heavy metals inside the cells of the biomass in the preparations of biocompost and biogas generation. It reduces the greenhouse gas emissions as compared with fossil fuels after that the end product can be utilized as a fertilizer in agriculture[37] thus, it creates sustainable environmental approach.

\section{Materials \& Methods:- \\ Collection area of algal biomass:}

The seaweed collection area was selected Beyt-dwarka near Okha, Gujarat, India situated geographically at Longitude - $68^{\circ} 20^{\prime} \mathrm{E}$ to $70^{\circ} 40^{\prime} \mathrm{E}$ and Latitude $-22^{\circ} 15^{\prime} \mathrm{N}$ to $23^{\circ} 40^{\prime} \mathrm{N}$. The collected algal species were named Caulerpa racemosa, Ulva lactuca and Kappaphycus alvarezii. The collected species were washed and cleaned by seawater to remove impurities, debris, sand particles and surface salt. Then it was transferred to laboratory to rewash it immediately with tap water. The extra water was removed by blotting paper and stored in refrigeration [30].

\section{Heavy Metal Analysis:-}

The effluent samples were taken for heavy metal analysis. The adsorbent free filtered waste water samples were the effluent of reactive red-195 (E1), Reactive red-145 (E4) and Reactive black-5 (E6) digested with aqua-regia of HCl: HNO3 $(1: 3 \mathrm{v} / \mathrm{v})$ in hot plate and then diluted with double distilled water. These light-yellow colored samples after digestion were analyzed for four different heavy metals such as chromium $(\mathrm{Cr})$, nickel $(\mathrm{Ni})$, copper $(\mathrm{Cu})$ and lead $(\mathrm{Pb})$ by Atomic Absorption Spectroscopy (Make-Shimadzu, Model-AA 7000) where the computer desktop is attached with the instrument so the results were digitized and printed [28]. The standard methods of APHA-AWWA, 1985 was applied[3].

\section{Estimation of Heavy metal removal by batch Experiments:-}

The dynamic biosorption of chromium $(\mathrm{Cr})$, nickel $(\mathrm{Ni})$, copper $(\mathrm{Cu})$ by algal biomass of Caulerpa racemosa, Ulva lactuca and Kappaphycus alvarezii was studied in batch experiments. It was carried out by taking $200 \mathrm{~mL}$ of dye effluents in conical flask of $500 \mathrm{~mL}$ by inoculating $2 \mathrm{~g}$ of Seaweed biomass in powdered form at $\mathrm{pH}$. To give better surface area if the algal biomass, interactions with effluents and proper ion transfer the batch experiments were conducted on flask shaker instrument with $80 \mathrm{rpm}$ of agitation speed at room temperature $28^{\circ} \mathrm{C}$. the sorption experiment was run for 90 minutes and each 10 minutes of interval the samples were taken out and filtered with Whatman paper number. 40 immediately to make effluent free from adsorbent biomass. This filtered effluents then analyzed with atomic absorption spectrophotometer (Make: UV-1800; Model: Shimadzu) to determine the residual metals. The equation is mentioned as below for equilibrium biosorptionqe $\left(\mathrm{mg} \mathrm{g}^{-1}\right)$ calculation

$q e=\frac{(\mathrm{Co}-\mathrm{Ce}) \mathrm{V}}{W}$

Where, $\mathrm{V}$ and $\mathrm{W}$ is the volume of the sample $(\mathrm{mL})$ and weight of the biomass $(\mathrm{g})$ and Co and Ce are the initial and equilibrium of dye effluents respectively. The equation for metal concentration adsorbed at time $\mathrm{t}$ as $\mathrm{qt}$ for $\mathrm{Cr}$, $\mathrm{Ni}$ and $\mathrm{Cu}$ was calculated as below Eq. (2)[40]:

$q t=\frac{(C o-C t) V}{W}$

Where, $\mathrm{V}$ and $\mathrm{W}$ are the volume of sample $(\mathrm{mL})$ and weight of biomass $(\mathrm{g})$ taken as adsorbent Co and Ct are the initial concentration (ppm) and the heavy metal concentration (ppm) in filtrate effluent taken at time $t$ respectively. $\mathrm{V}$ is the volume of the sample $(\mathrm{mL})$; and $\mathrm{W}$ is the weight of the biomass $(\mathrm{g})$ taken as adsorbent. The biosorption yield in percentage was studied by below equation (3)[21]

Biosorption yield $(\%)=\frac{C o-C t}{C o} \times 100$

\section{Optimization of Biocompost and Biogas potential of accumulated algal biomass \\ Biocompost Preparation:-}

The accumulated seaweeds were utilized for the biocompost preparation and its biofertilizing potential was studied. Biocompost was prepared from the kitchen waste, dye accumulated seaweed biomass, cattle dung, dry and green leaves and soil. The glass cylindrical chamber was taken, at first the thinner layer of soil was prepared inside the 
chamber, then moist cattle dung was added, in next layer the accumulated algal biomass was added, then 2-3 layers of wet and dry leaves, kitchen waste, waste fodder was added. sprinkle the water to maintain moisture level upto 60$70 \%$ in chamber and then cover the layer with cow dung slurry, kitchen waste and waste fodder mixed with moist soil. Repeat this system till the chamber is full, cover the chamber by fodder waste and heap the soil till the shape gets convex. Close the chamber by lid for 6-8 weeks[10][36]. After the compost produced, its component analysis was conducted such as organic carbon, nitrogen, phosphorus, potassium and carbon-nitrogen ratio in percentage and the data were compared with Govt. guideline specifications of organic fertilizer to determine its feasibility for application[5].

\section{Bio fertilizing potential:-}

The prepared biocompost was studied for its potential effect on germination of Vigna radiata and Triticum aestivum seeds; the control was taken as without compost containing soil. After the germination of seeds, the pigment content such as chlorophyll a, chlorophyll b, total chlorophyll and carotenoid of both the species was studied as qualitative analysis [39]. Thus, the experiment was conducted to determine the biofertilizing potential of accumulated algal biocompost for its applicability on the field. Thus, accumulated algal biomass performs as by product generated from waste water treatment.

\section{Biogas Generation:-}

The accumulated algal compost was further used to study its potential in biogas generation. It was studied by preparing the mixture of compost and accumulated seaweeds and keeping this mixture inside anaerobic chamber for 60 days, then the presence of methane as biogas was detected by gas chromatography (GC analysis) at SICART. The biogas yield was measured by following equation.

$$
\text { Biogas yield }(\%)=\frac{\text { Final weight of cylinder }- \text { Initial weight of cylinder }}{\text { Initial weight of cylinder }} \times 100
$$

\section{Result and Discussion:-}

Heavy Metals:-

As per the General Standards of The Environment Protection Rules, 1986 (Schedule-4) [38] the metal content in waste water was below the permitted limits given for the aquatic coastal area except the copper $(\mathrm{Cu})$. The MOEF Standard value for chromium $(\mathrm{Cr})$, nickel $(\mathrm{Ni})$, copper $(\mathrm{Cu})$ and lead $(\mathrm{Pb})$ given as $2 \mathrm{mg} \mathrm{L}^{-1}, 3 \mathrm{mg} \mathrm{L}^{-1}, 3 \mathrm{mg} \mathrm{L}^{-1}, 0.1$ $\mathrm{mg} \mathrm{L}^{-1}$ respectively. The heavy metal concentration of $\mathrm{Cr}, \mathrm{Ni}, \mathrm{Cu}$ and $\mathrm{Pb}$ were determined in present study. The highest concentration was observed for copper (Cu) as $16.865 \mathrm{mg} \mathrm{L}^{-1}$ (E4) and $16.048 \mathrm{mg} \mathrm{L}^{-1}$ (E6). The chromium $(\mathrm{Cr})$ and nickel $(\mathrm{Ni})$ was found present in all effluent samples. The concentration of chromium $(\mathrm{Cr})$ was observed maximum $0.6573 \mathrm{mg} \mathrm{L}^{-1}$ (E1) and minimum $0.1376 \mathrm{mg} \mathrm{L}^{-1}$ (E6). Whereas nickel (Ni) was observed maximum $0.2054 \mathrm{mg} \mathrm{L}^{-1}(\mathrm{E} 4)$ and minimum $0.174 \mathrm{mg} \mathrm{L}^{-1}(\mathrm{E} 1)$. (Table1). The heavy metal lead $(\mathrm{Pb})$ was observed below detectable limit (BDL) in all the effluent samples. Similarly, the copper $(\mathrm{Cu})$ was observed below detectable limit (BDL) in E1 effluent. It was reported that the bioaccumulation of heavy metals in flora and fauna increases if the metal content in water increases, because the metal uptake by living organisms becomes rapid than the excretion phase[19].

Table1:-Heavy Metal Analysis

\begin{tabular}{|c|c|c|c|c|}
\hline Heavy Metal & $\begin{array}{l}\text { Chromium } \\
\text { (Cr) }\end{array}$ & $\begin{array}{l}\text { Nickel } \\
(\mathrm{Ni})\end{array}$ & $\begin{array}{l}\text { Copper } \\
(\mathrm{Cu})\end{array}$ & $\begin{array}{l}\text { Lead } \\
(\mathrm{Pb})\end{array}$ \\
\hline E1 $\left(\mathrm{mg} \mathrm{l}^{-1}\right)$ & 0.6573 & 0.174 & - & - \\
\hline $\mathrm{E} 4\left(\mathrm{mg} \mathrm{l}^{-1}\right)$ & 0.5179 & 0.2054 & 16.865 & - \\
\hline E6 $\left(\mathrm{mg} \mathrm{l}^{-1}\right)$ & 0.1376 & 0.1754 & 16.048 & - \\
\hline
\end{tabular}

(E1- Effluent of Reactive red-195; E4- Effluent of Reactive yellow-145; E6- Effluent of Reactive black-5)

Determination of heavy metal removal potential of Caulerpa racemosa, Ulva lactuca and Kappaphycus alvarezii from effluents as biosorption study:-

The heavy metal sorption was studied to determine potential level of Seaweed. It was explored under 10 to 90 minutes of contact time; the sample was taken out at each 10 minutes of time interval. The Fig. 2 to Fig. 6 indicates quantity absorbed in $\mathrm{mg} \mathrm{g}^{-1}$ as a function of contact time by algal biomass of Caulerpa racemosa, Ulva lactuca and Kappaphycus alvarezii with heavy metals chromium, nickel and copper. This study reveals that the algal biomass shows rapid adsorption initially and then it reaches to equilibrium and it the adsorption slowly lowers. 


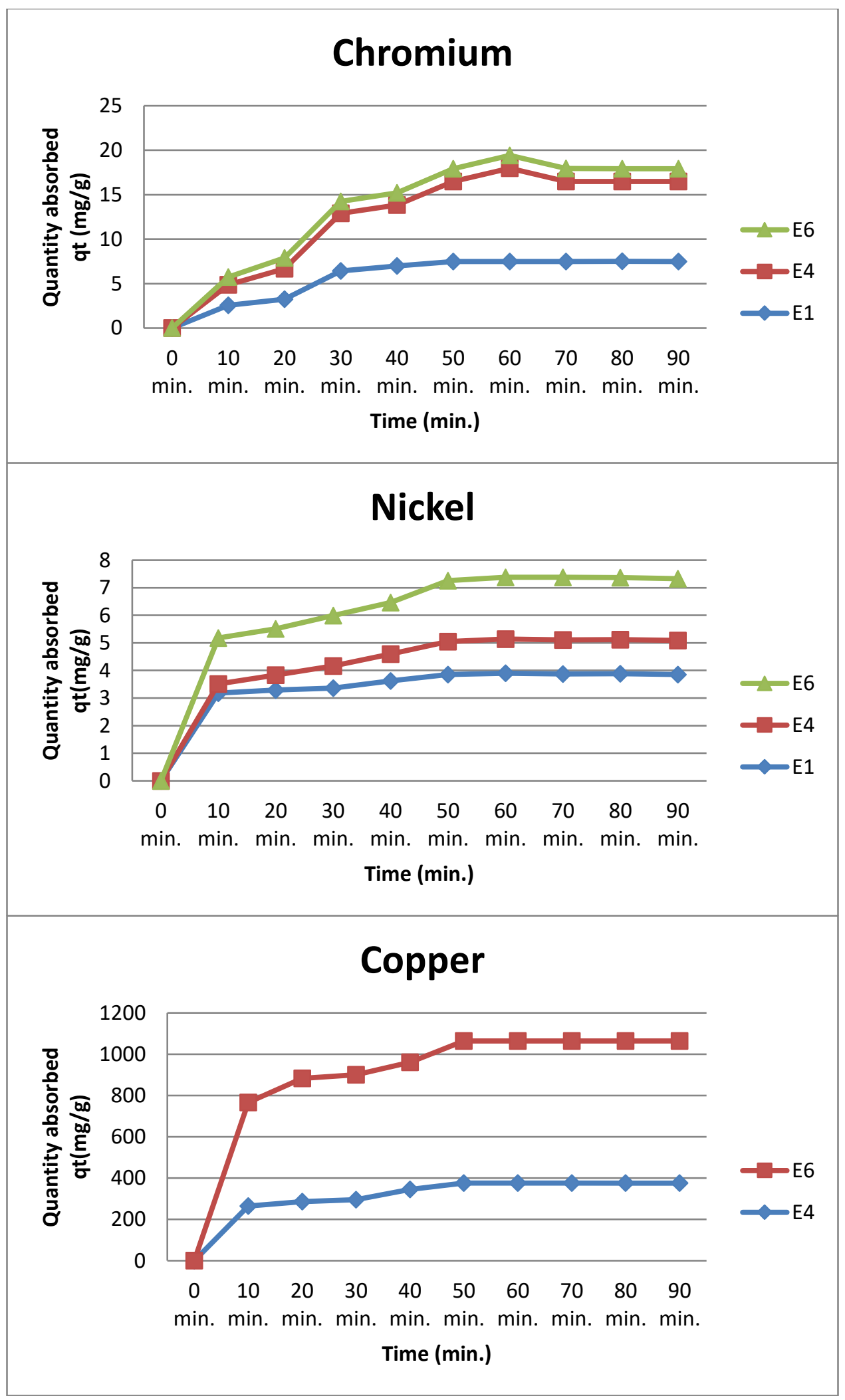

Fig. 2:-Biosorption capacity of Caulerpa racemosa as function of contact time 


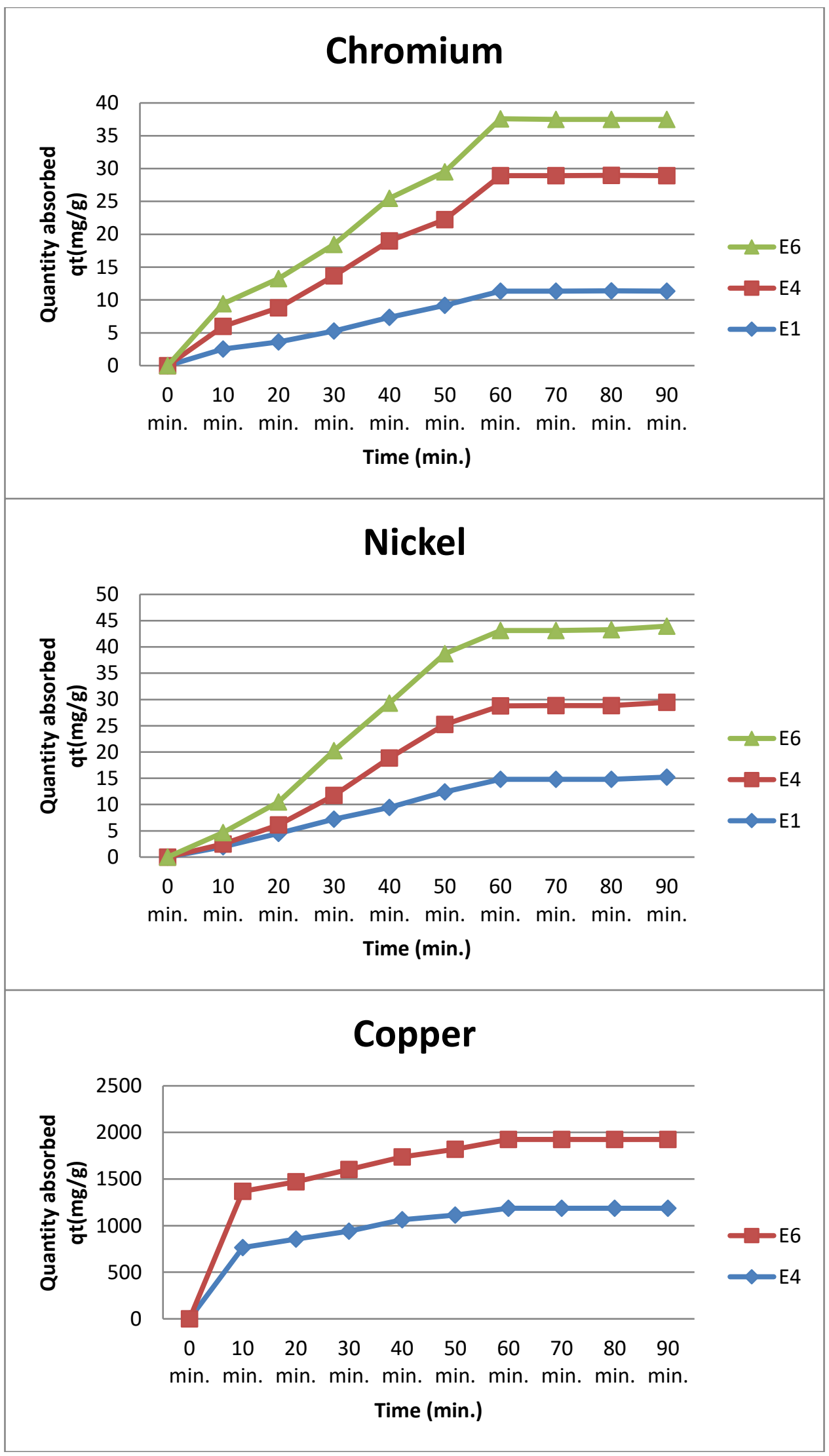

Fig. 3:-Biosorption capacity of Ulva lactuca as function of contact time 

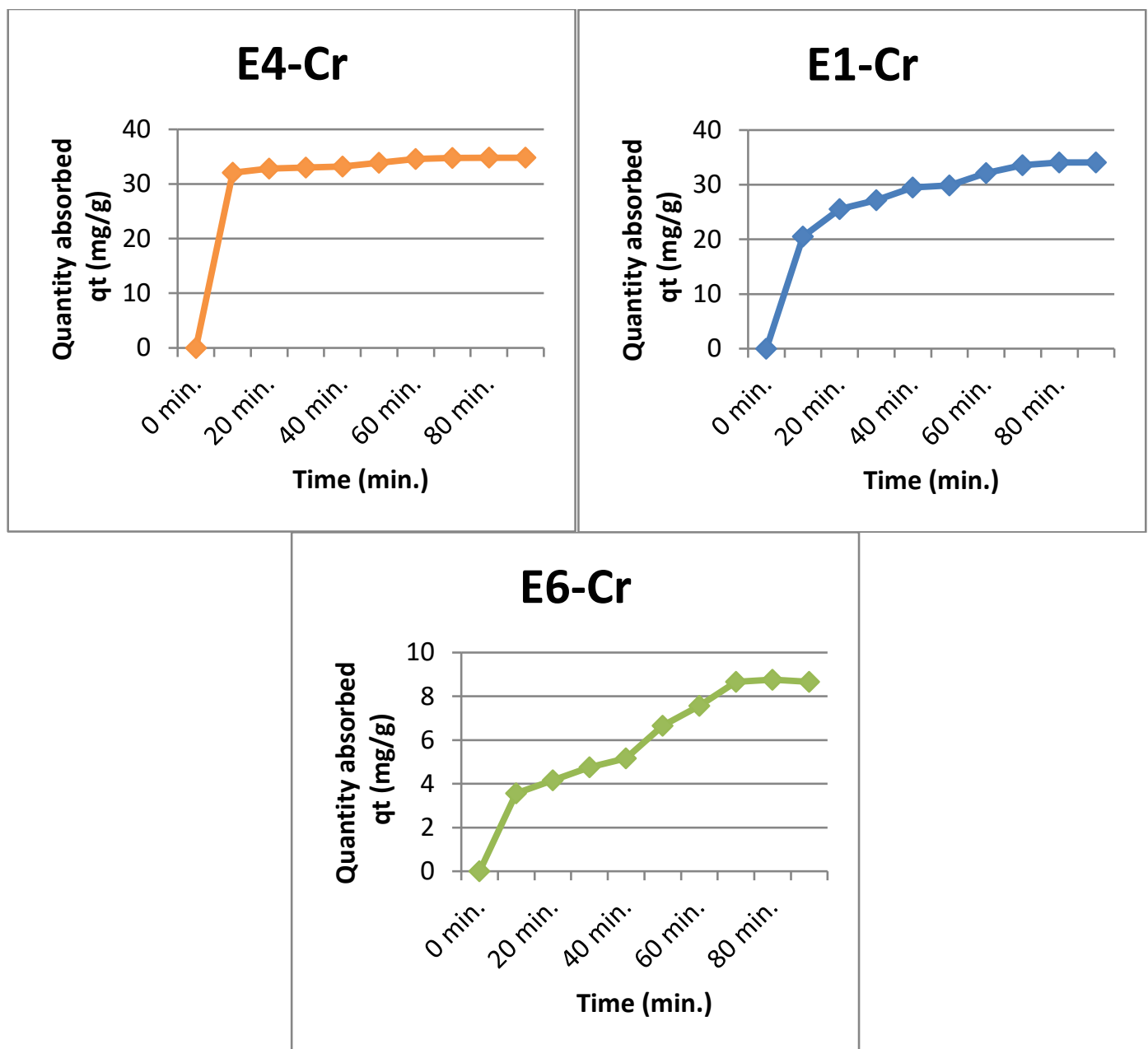

Fig. 4:-Biosorption capacity of Kappaphycus alvarezii for Chromium as function of contact time

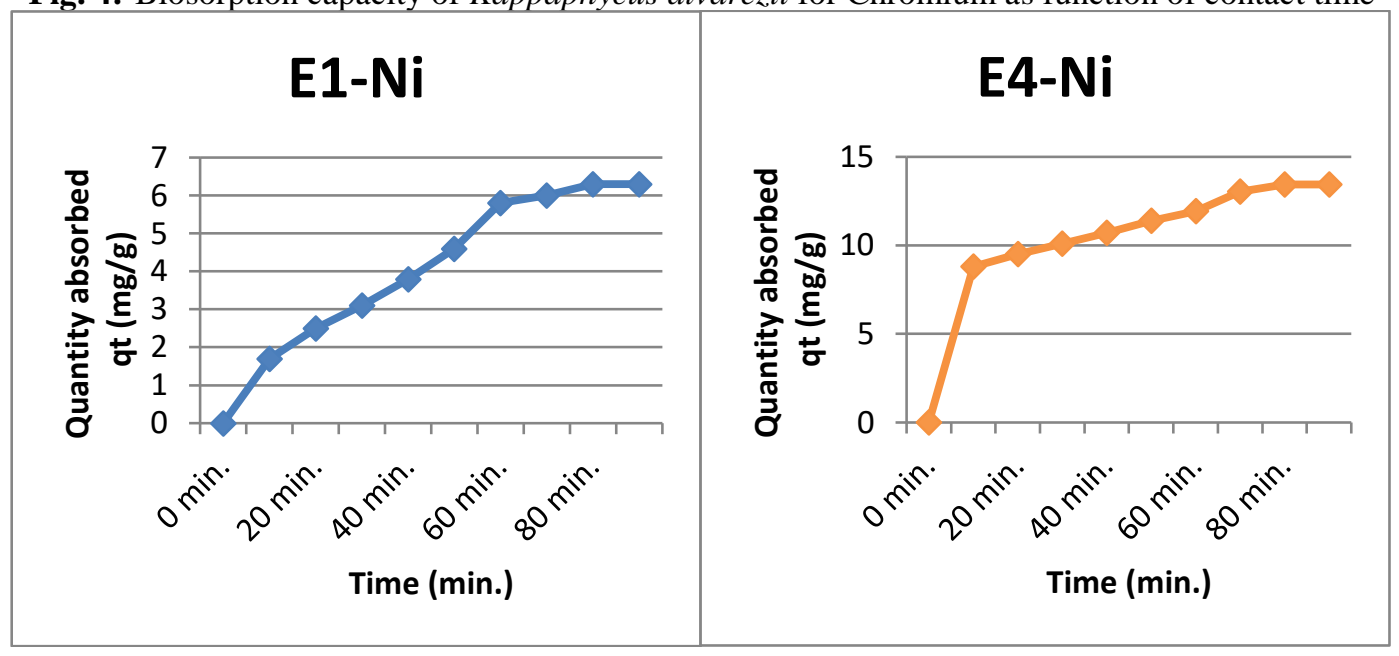




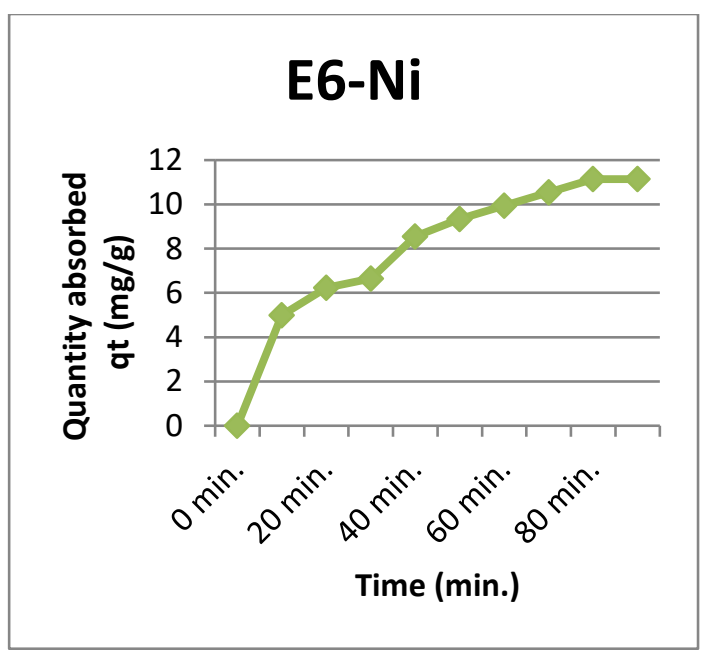

Fig. 5:-Biosorption capacity of Kappaphycus alvarezii for Nickel as function of contact time

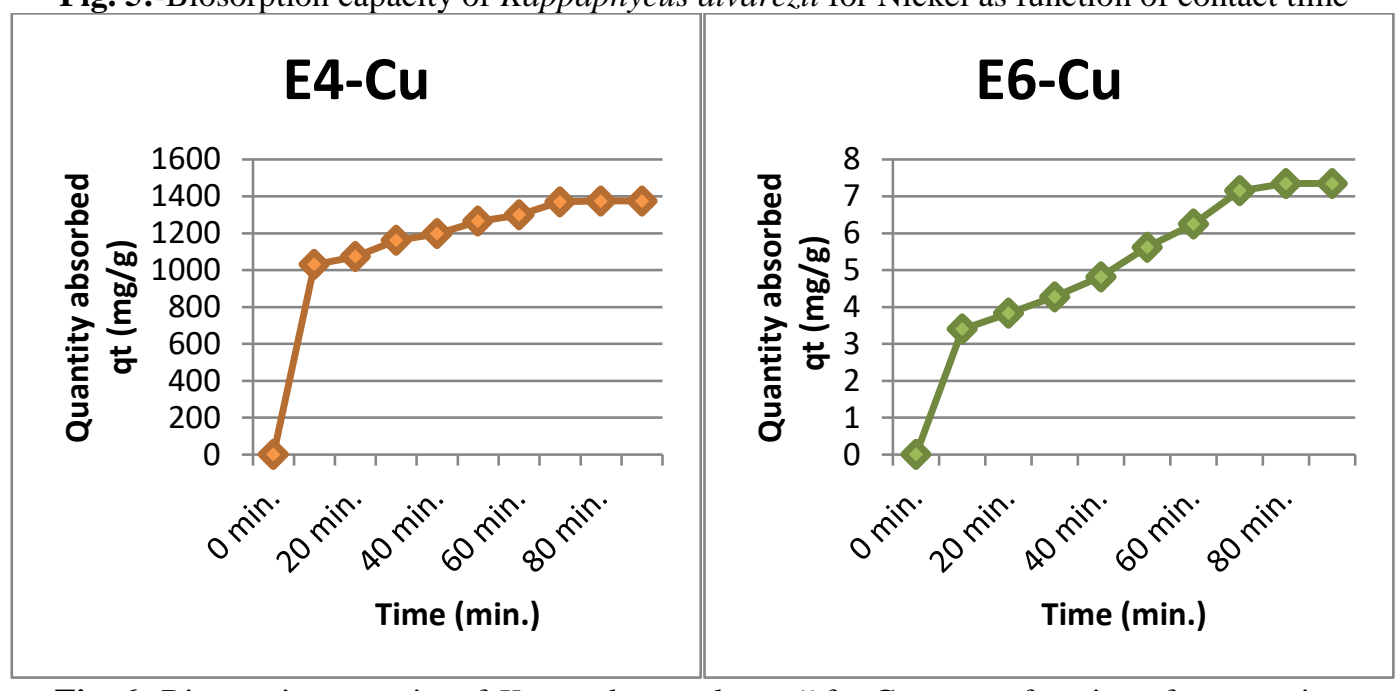

Fig. 6:-Biosorption capacity of Kappaphycus alvarezii for Copper as function of contact time

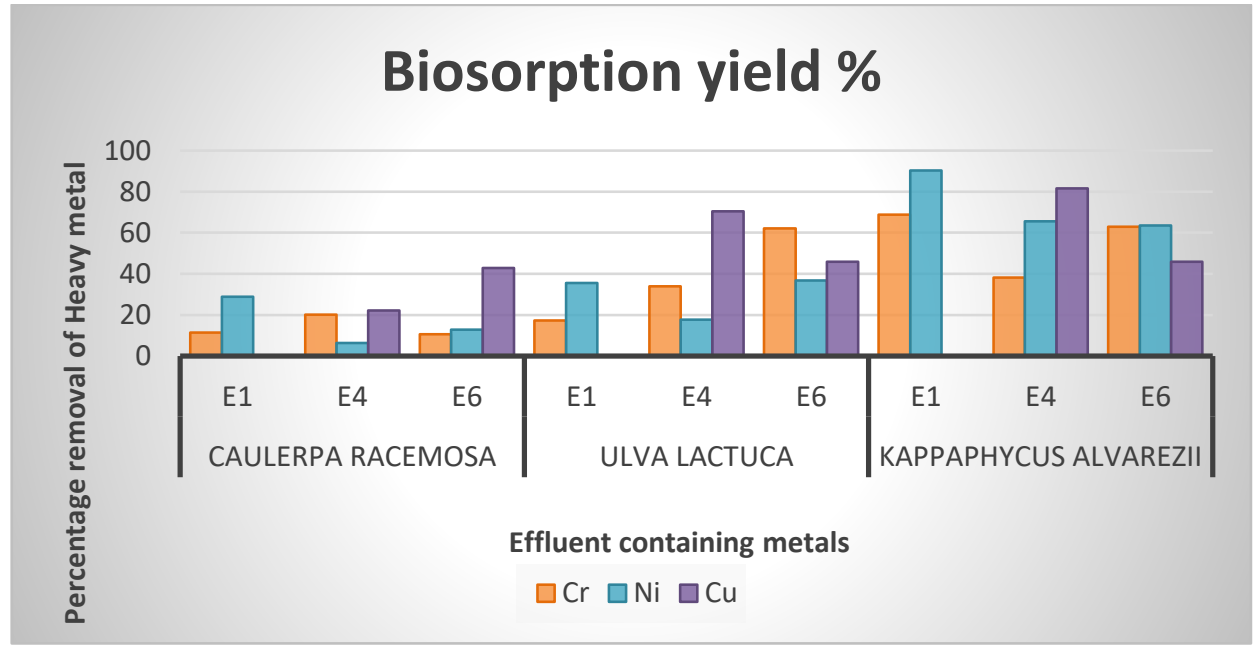

Fig. 7:-Biosorption Potential of seaweeds with Effluents

It was occurred due to the minimum accessibility of vacant places in biomass surface and repulsive forces of particles minimize the rate of adsorption. Intraparticle diffusion is also one of the reasons to reach the equilibrium in 
rate of adsorption inside the algal biomass cells from bulk to surface [21]. Therefore, this process dependent on diffusion and attraction forces inside the molecules and vacant space availability on the surface of the biomass. Similar study was reported by many scientists in biosorption of toxic metals such as chromium, cadmium, copper and nickel [13][6][7][20][33][1].

Fig. 7 shows percentage removal of heavy metals by algal biomass of Caulerpa racemosa, Ulva lactuca and Kappaphycus alvarezii from the effluents E1, E4 and E6 for chromium, nickel, copper. The maximum biosorption yield of chromium, nickel and copper in Caulerpa racemosa was observed as $20.23 \%$ in E4, $28.84 \%$ in E1 and $42.91 \%$ in E6 effluents respectively. Ulva lactuca gives maximum biosorption yield for $\mathrm{Cr}$ was $62.2 \%$ in $\mathrm{E} 6$, $\mathrm{Ni}$ observed as $35.63 \%$ in E1 and $70.35 \% \mathrm{Cu}$ in E4 effluent. Kappaphycus alvarezii received maximum metal removal amongst remaining two algal biomass as $68.78 \%$ (E1) for $\mathrm{Cr}, 90.22 \%$ (E1) for $\mathrm{Ni}$ and $81.53 \%$ (E4) for Cu. It was observed from the figure that all three-algal biomass shows good biosorption potential for $\mathrm{Cu}$. Many reports are available on biosorption of metals under 250 minutes and 180 minutes' time period for green, red and brown seaweed biomass [4][12][32]. Kappaphycus alvarezii indicates major attraction towards metals which is depended on hydrolysis constant, ionic charge and ionic size of the respective heavy metal [1][20][25]. Thus, the present study revealed that Kappaphycus alvarezii indicates good potential in removal of heavy metals as compare to Caulerpa racemosa and Ulva lactuca.

\section{Evaluation of biocompost prepared from accumulated algae and its fertilizingpotential on germination:-}

The seaweed biomass was used to treat industrial dye waste water, after the treatment this accumulated Seaweed biomass were utilized to prepare algal biocompost (Fig. 8). The compost generated were analyzed for the total organic carbon, total nitrogen, total phosphates, total potash and $\mathrm{C} / \mathrm{N}$ ratio which was observed as $16.87 \%, 0.6 \%$, $0.32 \%, 0.58 \%, 28.11$ in Caulerpa racemosa (A), $15.54 \%, 0.8 \%, 0.36 \%, 0.72 \%, 19.42 \%$ in Ulva lactuca (B) and $20.45 \%, 0.90 \%, 0.30 \%, 0.53 \%$ and 22.72 in Kappaphycus alvarezii (C) respectively (Table2). The data were compared with the Indian Govt. standards of organic fertilizer which shows that the accumulated algal compost possess good potential as biofertilizer because the values are nearer to specifications indicates its applicability as biofertilizer. The algal compost prepared from anaerobic digestion remains a potential source of nitrogen and phosphorus as a fertilizer [41]. Thus, it becomes sustainable method to use accumulated algae as by product in preparations of biocompost and source of biogas generation which generates no secondary waste in effluent treatment plants, it is described by few literature studies as algae are important source for use it as bio fuel from codigesting it with the cattle manure anaerobically, Seaweed Ulva lactuca and Laminaria digitate were used in codigestion with cattle manure anaerobically for biogas production which reveals the mesophilic digestion observed stable as compared with thermophilic digestion comprising with different types of feeding. Laminria gives higher methane yield than Ulvain thermophilic anaerobic digestion[34]. Also, the accumulated algae used in present study to generate biogas similar study was conducted to evaluate the biogas potential of heavy metal accumulated green algae Spirogyra and Oscillatoria Sp. which reveals algal compost content such as organic carbon, nitrogen, phosphorus and potassium recorded lower in $30 \mathrm{ppm}$ and higher in $2 \mathrm{ppm}$ of heavy metal dose and highest biogas yield was recorded at $30 \mathrm{ppm}$ heavy metal dose in fresh algal compost of Spirogyra sp. and Oscillatoria sp. respectively [10]. The prepared manure using farmyard waste and compared the plant nutrients such as nitrogen, phosphorus, potassium with the municipal waste compost observed as $0.96 \%, 75 \%, 0.33 \%$ respectively in the municipal waste compost which observed lower as compared with the farmyard waste manure observed as $2.5 \%$, $1.60 \%$ and $1.70 \%$ respectively[17]. The different concentration of biogas yield can be attributed due to cell wall of the alga and its biochemical composition and also the type of reactor and operational conditions applied [22]. Although our results support the accumulated seaweeds to produce biocompost followed by biogas generation from the literature findings.

The compost was studied for its potential by experimenting germination of Vigna radiata and Triticum aestivum with its pigment content analysis which is shown in Fig. 9 and Fig. 10. The study indicates the good level of pigment content present in plants as compared with control and germination was found better as compare to control (Table-3 and Table-4). The without compost containing soil is taken as control. The control values in Vigna radiata for chlorophyll-a, chlorophyll-b, total chlorophyll and carotenoids indicates $0.428 \mathrm{mg} \mathrm{g}^{-1}, 0.623 \mathrm{mg} \mathrm{g}^{-1}, 1.051 \mathrm{mg} \mathrm{g}^{-}$ ${ }^{1}, 0.164 \mu \mathrm{g} \mathrm{g}^{-1}$ respectively. The algal compost applied on Vigna radiata plants receives $0.305 \mathrm{mg} \mathrm{g}^{-1}, 0.355 \mathrm{mg} \mathrm{g}^{-1}$, $0.66 \mathrm{mg} \mathrm{g}^{-1}$ and 0.004 in Caulerpa racemosa, $0.331 \mathrm{mg} \mathrm{g}^{-1}, 0.391 \mathrm{mg} \mathrm{g}^{-1}, 0.722 \mathrm{mg} \mathrm{g}^{-1}$ and $0.191 \mu \mathrm{g} \mathrm{g}^{-1}$ in Ulva lactuca, $0.323 \mathrm{mg} \mathrm{g}^{-1}, 0.424 \mathrm{mg} \mathrm{g}^{-1}, 0.722 \mathrm{mg} \mathrm{g}^{-1}$ and $0.153 \mu \mathrm{g} \mathrm{g}^{-1}$ in Kappaphycus alvarezii respectively. It shows that the values of the compost applied plants are slightly lowered than control but nearer to control which shows the applicability of compost on Vigna radiata seeds that gives effective germination. In Triticum aestivum the control 
values observed as $0.72 \mathrm{mg} \mathrm{g}^{-1}, 0.24 \mathrm{mg} \mathrm{g}^{-1}, 0.96 \mathrm{mg} \mathrm{g}^{-1}$ and $0.97 \mu \mathrm{g} \mathrm{g}^{-1}$ for the chlorophyll-a, chlorophyll-b, total chlorophyll and carotenoids respectively. Whereas in Caulerpa racemosa, Ulva lactuca and Kappaphycus alvarezii the values observed as $1.48 \mathrm{mg} \mathrm{g}^{-1}, 0.99 \mathrm{mg} \mathrm{g}^{-1}, 2.08 \mathrm{mg} \mathrm{g}^{-1}$ and $1.66 \mu \mathrm{g} \mathrm{g}^{-1} ; 1.63 \mathrm{mg} \mathrm{g}^{-1}, 0.64 \mathrm{mg} \mathrm{g}^{-1}, 2.27 \mathrm{mg} \mathrm{g}^{-1}$ and $1.65 \mu \mathrm{g} \mathrm{g}^{-1} ; 1.59 \mathrm{mg} \mathrm{g}^{-1}, 2.31 \mathrm{mg} \mathrm{g}^{-1}, 3.91 \mathrm{mg} \mathrm{g}^{-1}$ and $1.60 \mu \mathrm{g} \mathrm{g}^{-1}$ for chlorophyll-a, chlorophyll-b, total chlorophyll and carotenoids respectively. The literature shows the accumulated algal compost application on germination. The studyon the phytotoxicity by applying treated and untreated dye on seeds of Triticum aestivum and found the germination in our study we applied dye accumulated algal compost on seeds of Triticum aestivum and Vigna radiata[9].

Table2:-Accumulated algal compost analysis

\begin{tabular}{|c|c|c|c|c|}
\hline Compost Analysis & $\begin{array}{c}\text { A } \\
\text { (Caulerpa racemosa) }\end{array}$ & $\begin{array}{c}\mathrm{B} \\
\text { (Ulva lactuca })\end{array}$ & $\begin{array}{c}\mathrm{C} \\
\text { (Kappaphycus alvarezii) })\end{array}$ & $\begin{array}{c}\text { Specifications } \\
\text { of Organic } \\
\text { Fertilizer } \\
\text { (Indian Govt. } \\
\text { guidelines) }\end{array}$ \\
\hline TOC & $16.87 \%$ & $15.54 \%$ & $20.45 \%$ & $12 \%$ \\
\hline Total Phosphorus & $0.32 \%$ & $0.36 \%$ & $0.3 \%$ & $0.80 \%$ \\
\hline Total Potassium & $0.58 \%$ & $0.72 \%$ & $0.52 \%$ & $0.40 \%$ \\
\hline Total Nitrogen & $0.6 \%$ & $0.8 \%$ & $0.9 \%$ & $0.40 \%$ \\
\hline C:N ratio & 28.11 & 19.42 & 22.72 & $<20$ \\
\hline
\end{tabular}

Table3:-Compost effect on germination of Triticum aestivum

\begin{tabular}{|c|c|c|c|c|}
\hline Triticum aestivum & Control & Caulerpa racemosa & Ulva lactuca & Kappaphycus alvarezii \\
\hline Chl-a $\left(\mathrm{mg} \mathrm{g}^{-1}\right)$ & $0.72 \pm 0.001$ & $1.48 \pm 0.354$ & $1.63 \pm 0.007$ & $1.59 \pm 0.003$ \\
\hline Chl-b $\left(\mathrm{mg} \mathrm{g}^{-1}\right)$ & $0.24 \pm 0.038$ & $0.99 \pm 0.101$ & $0.64 \pm 0.081$ & $2.31 \pm 1.30$ \\
\hline Total Chl. $\left(\mathrm{mg} \mathrm{g}^{-1}\right)$ & $0.96 \pm 0.040$ & $2.08 \pm 0.241$ & $2.27 \pm 0.083$ & $3.91 \pm 1.29$ \\
\hline Carotenoid $\left(\mu \mathrm{g} \mathrm{g}^{-1}\right)$ & $0.97 \pm 0.009$ & $1.66 \pm 0.082$ & $1.65 \pm 0.091$ & $1.60 \pm 0.096$ \\
\hline
\end{tabular}

Table4:-Compost effect on germination of Vigna radiata

\begin{tabular}{|c|c|c|c|c|}
\hline Vigna radiata & Control & Caulerpa racemosa & Ulva lactuca & Kappaphycus alvarezii \\
\hline Chl-a $\left(\mathrm{mg} \mathrm{g}^{-1}\right)$ & $0.428 \pm 0.006$ & $0.305 \pm 0.001$ & $0.331 \pm 0.0004$ & $0.323 \pm 0.0008$ \\
\hline Chl-b $\left(\mathrm{mg} \mathrm{g}^{-1}\right)$ & $0.623 \pm 0.0007$ & $0.355 \pm 0.0004$ & $0.391 \pm 0.0005$ & $0.424 \pm 0.001$ \\
\hline Total Chl $\left(\mathrm{mg} \mathrm{g}^{-1}\right)$ & $1.051 \pm 0.006$ & $0.66 \pm 0.001$ & $0.722 \pm 0.0009$ & $0.722 \pm 0.0009$ \\
\hline Carotenoid $\left(\mathrm{\mu g} \mathrm{g}^{-1}\right)$ & $0.164 \pm 0.001$ & $0.004 \pm 0.0002$ & $0.191 \pm 0.0007$ & $0.153 \pm 0.0007$ \\
\hline
\end{tabular}

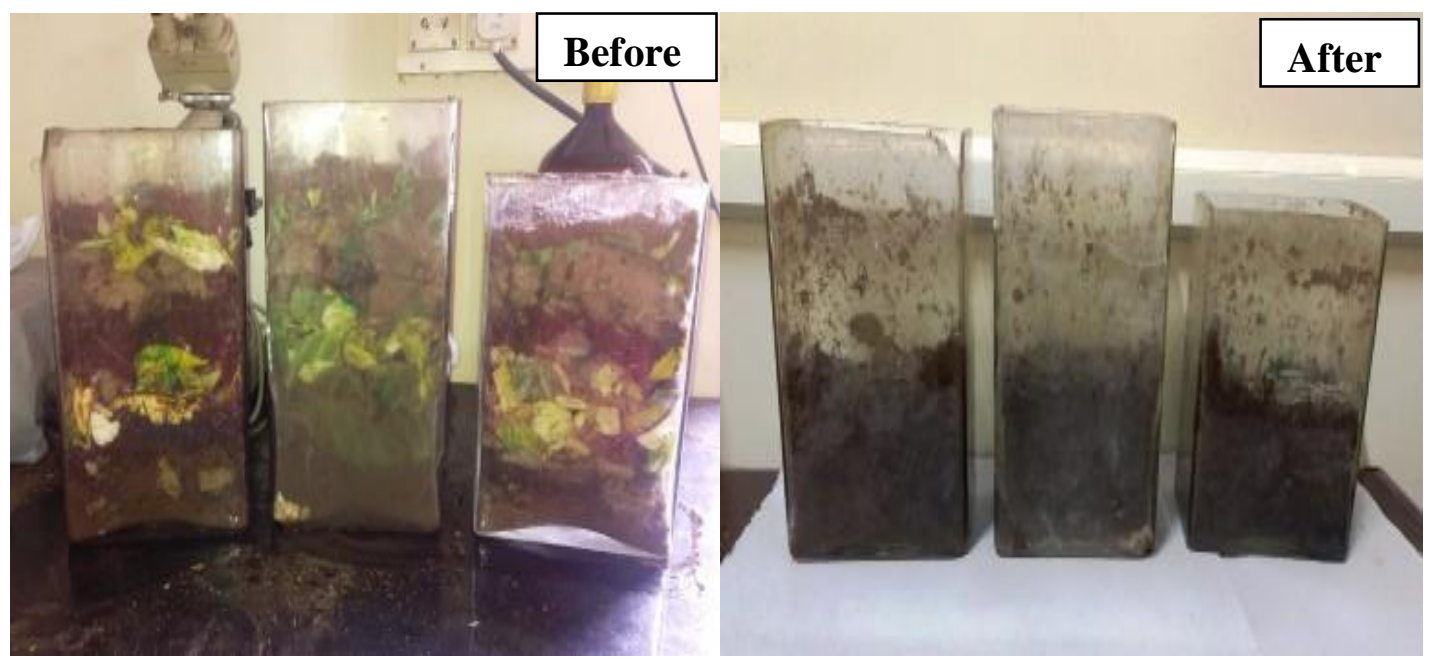

Fig. 8:-Biocompost Assembly 


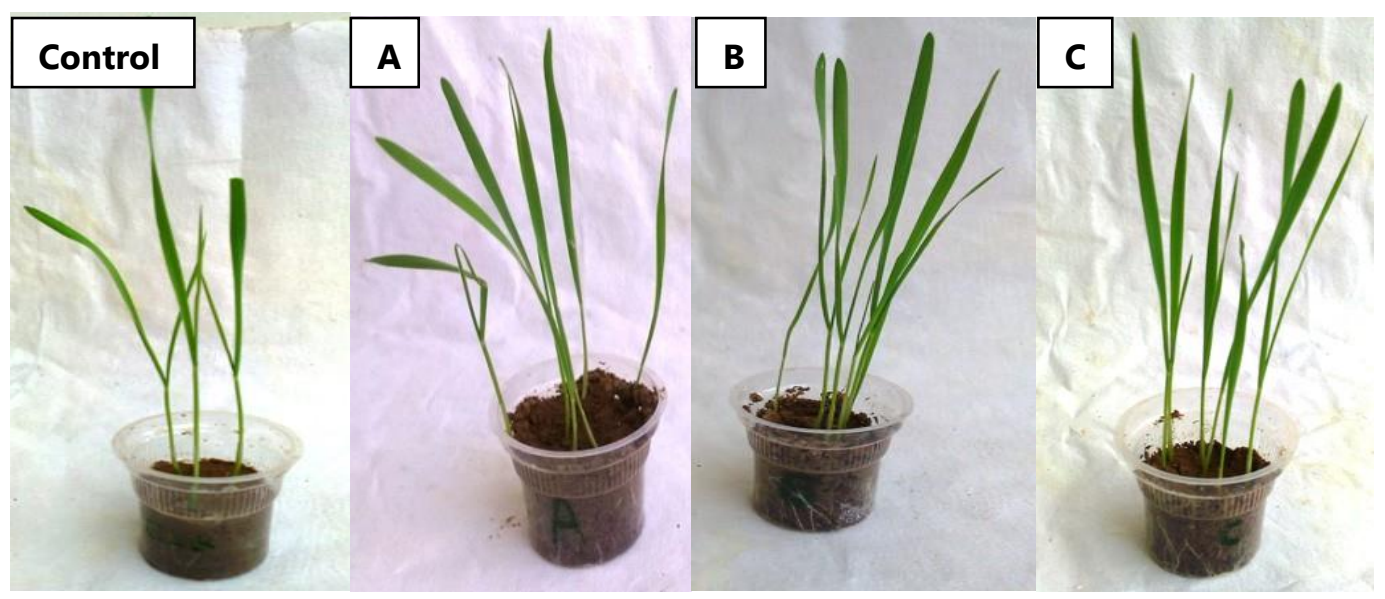

(Where, A is Caulerpa racemosa, B is Ulva lactuca and C is Kappaphycus alvarezii)

Fig. 9:-Germination of Triticum aestivum

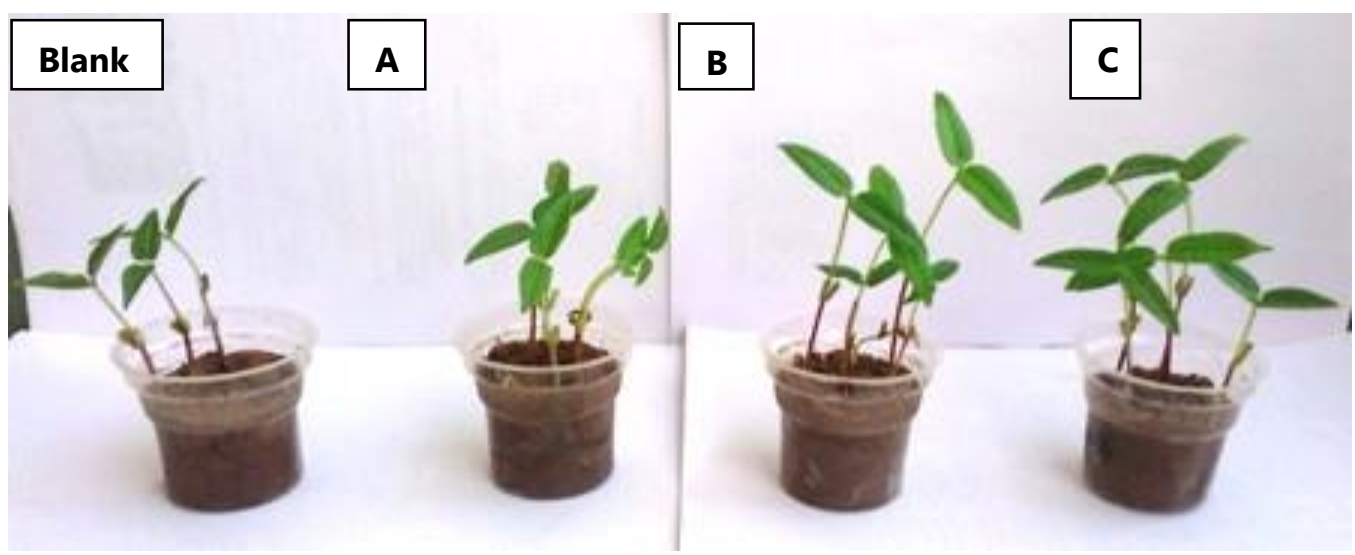

(Where, A is Caulerpa racemosa, B is Ulva lactuca and C is Kappaphycus alvarezii)

Fig. 10:-Germination of Vigna radiata

\section{Biogas generation from dye accumulated seaweed compost:-}

Table-5 indicates the results of the biogas yield for each Caulerpa racemosa (A), Ulva lactuca (B) and Kappaphycus alvarezii $(\mathrm{C})$. The methane concentration in percentage was calculated from the GC-plot, by comparing the value with the standard methane (99.5 \%) GC graph (Fig. 12 to Fig. 15). Highest biogas was observed in slurry of Caulerpa racemosa $(23.90 \%)$ followed by Kappaphycus alvarezii $(21.39 \%)$ and lowest biogas yield was observed in slurry of Ulva lactuca (17.29\%). The order of the biogas yield is represented as Caulerpa racemosa > Kappaphycus alvarezii > Ulva lactuca (Table 5). A review on the biogas production from macro algae by taking the European case study in which the macroalgal culture on wide scale to produce biogas was developed in 1960's but due to farming challenges and engineering tools it fails to produce. From last 50 years in China and Asia, the mass production of the seaweeds has been developed and also tested in America and Europe. To high methane yield by gasification of macro algae, large scale cultivation was developed as field scale trials [18]. The algal culture of Chlorella vulgaris was used to study the nutrient removal from domestic waste water, microalgal slurry from the effluent was studied for its potential in biogas production by applying anaerobic digestion which indicates that methane yield was observed higher than the untreated algal biomass [11]. Thus, seaweeds play as an important role in biogas production. By coupling the renewable energy production with waste water treatment can enhance the sustainability of waste water treatment by reducing the cost and sludge generation [37].

Table5:-Biogas yield

\begin{tabular}{|l|l|l|l|}
\hline & Caulerpa racemosa & Ulva lactuca & Kappaphycus alvarezii \\
\hline Biogas yield (\%) & $23.90 \%$ & $17.29 \%$ & $21.39 \%$ \\
\hline $\begin{array}{l}\text { Methane Concentration } \\
\text { from GC }\end{array}$ & $33.73 \%$ & $30.80 \%$ & $33.02 \%$ \\
\hline
\end{tabular}




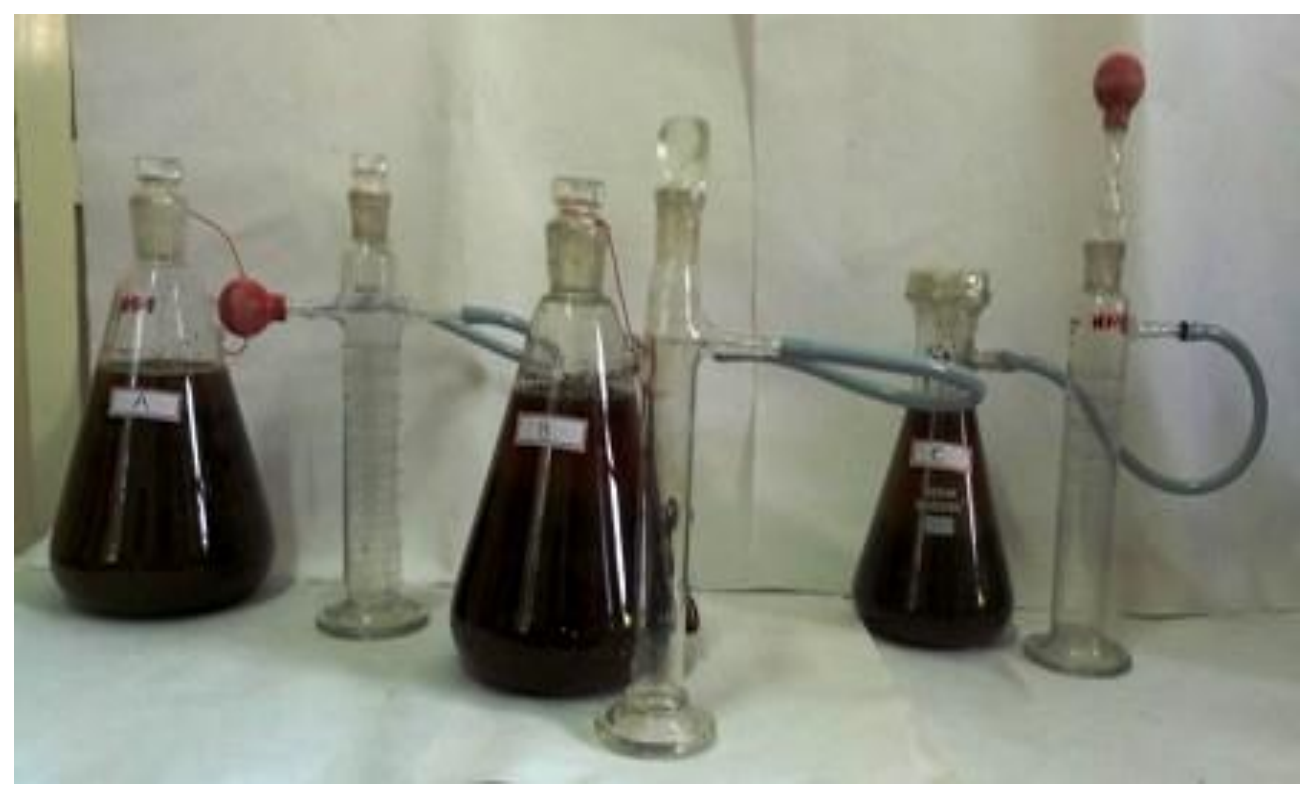

Fig.11:-Biogas Reactor

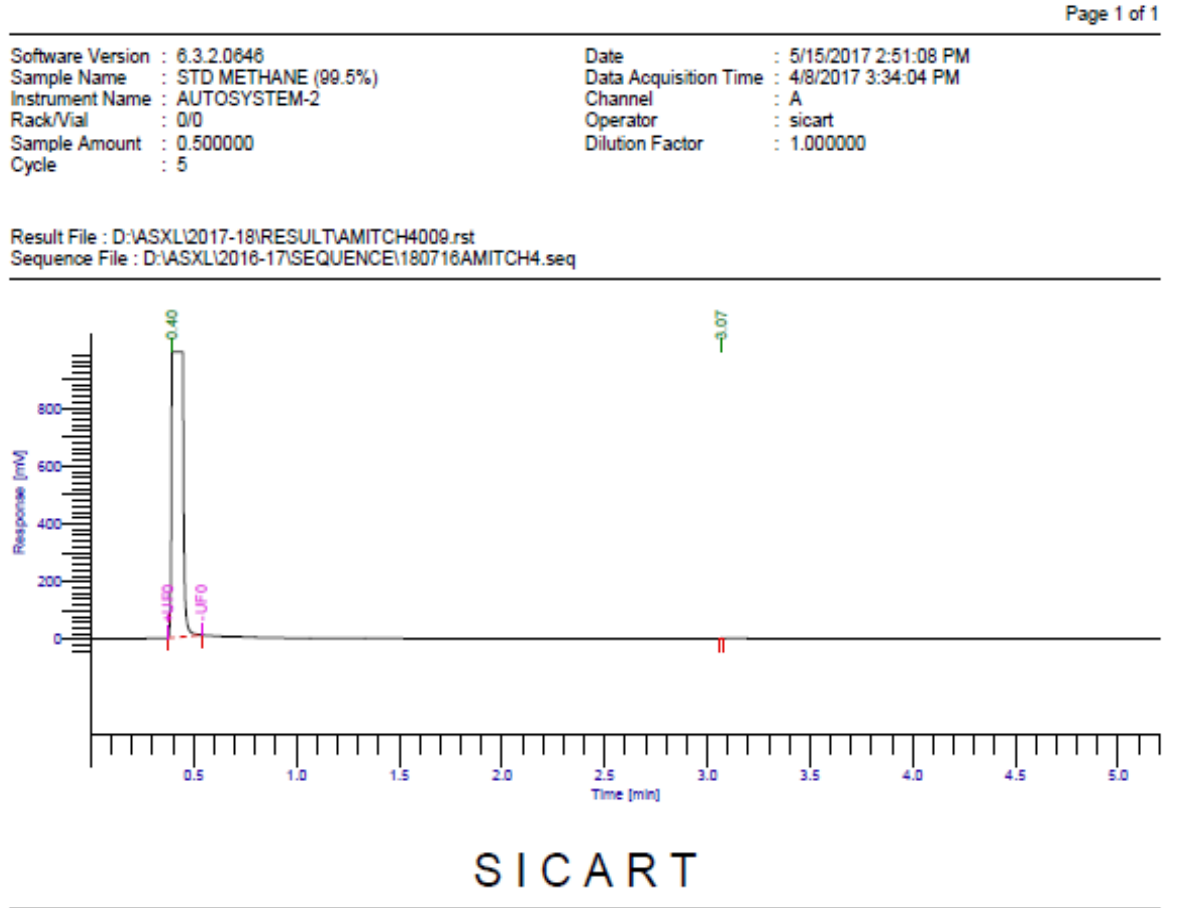

SHOPHISTICATED INSTRUMENTATION CENTRE FOR APPLIED RESEARCH AND TESTING

\begin{tabular}{|c|c|c|c|c|c|}
\hline $\begin{array}{c}\text { Peak } \\
\#\end{array}$ & $\begin{array}{l}\text { Component } \\
\text { Name }\end{array}$ & $\begin{array}{l}\text { Time } \\
\text { [min] }\end{array}$ & $\begin{array}{c}\text { Area } \\
\text { [uV'sec] }\end{array}$ & $\begin{array}{l}\text { Height } \\
\text { [uV }]\end{array}$ & $\begin{array}{l}\text { Area } \\
{[\%]}\end{array}$ \\
\hline & & $\begin{array}{l}0.397 \\
3.071\end{array}$ & $\begin{array}{r}3738189.58 \\
87.53\end{array}$ & $\begin{array}{r}986875.64 \\
196.73\end{array}$ & $\begin{array}{r}100.00 \\
0.00\end{array}$ \\
\hline & & & 3738287.1 & 2 & 100.00 \\
\hline
\end{tabular}

Warning - Signal level out-of-range in peak

SICART-CVM, VALLABH VIDYANGAR- 388120

Fig. 12:-Plot of Standard methane (99.5\%) 


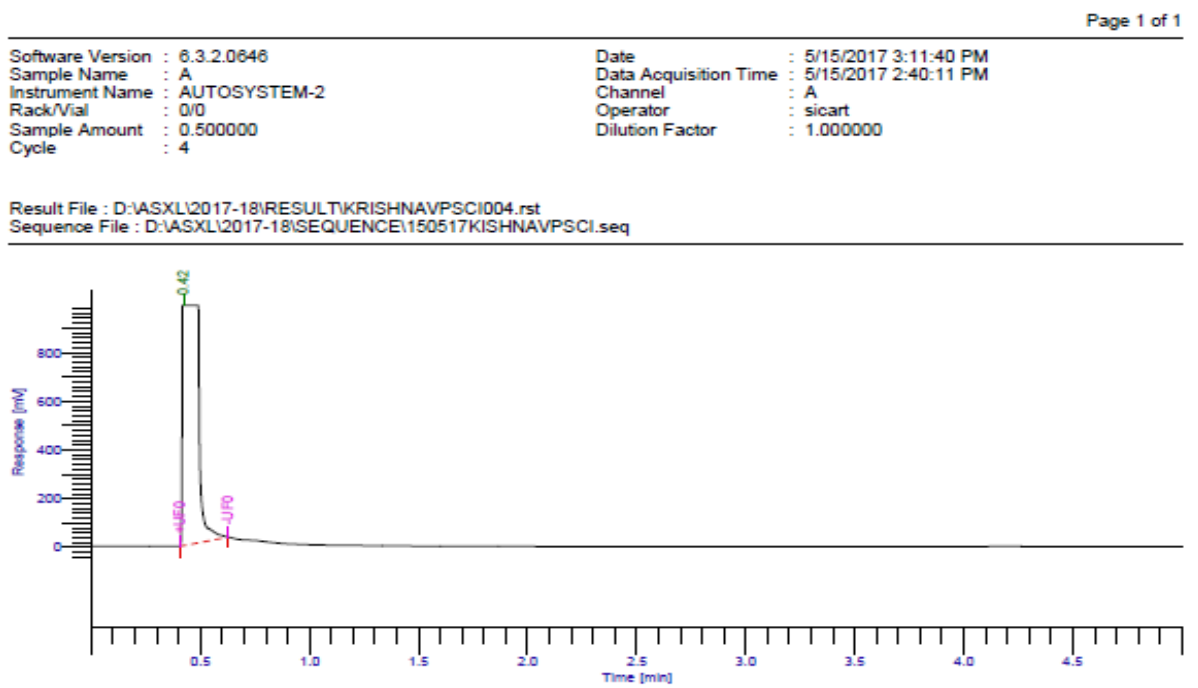

\section{SICART}

SHOPHISTICATED INSTRUMENTATION CENTRE FOR APPLIED RESEARCH AND TESTING

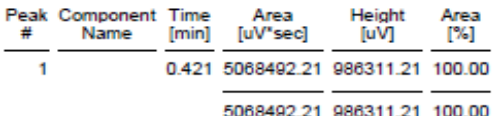

Warning - Signal level out-of-range in peak

SICART-CVM, VALLABH VIDYANGAR- 388120

Fig. 13:- Gas chromatography of Caulerpa racemosa biogas reactor

\begin{tabular}{|c|c|c|c|}
\hline & & & \\
\hline $\begin{array}{l}\text { Software Version } \\
\text { Sample Name } \\
\text { Instrument Name } \\
\text { RackNVial } \\
\text { Sample Amount } \\
\text { Cycle }\end{array}$ & $\begin{array}{l}6.3 .2 .0846 \\
\text { B } \\
\text { AUTOSYSTEM-2 } \\
\text { ONO } \\
0.500000 \\
3\end{array}$ & $\begin{array}{l}\text { Date } \\
\text { Data Acquisition Time } \\
\text { Channel } \\
\text { Operator } \\
\text { Dilution Factor }\end{array}$ & $\begin{array}{l}\text { 5/15/2017 3:09:48 PM } \\
\text { 5/15/2017 2:30:12 PM } \\
\text { A } \\
\text { sicart } \\
1.000000\end{array}$ \\
\hline $\begin{array}{l}\text { Result File: D:lA } \\
\text { Sequence File : }\end{array}$ & $\begin{array}{l}\text { I2017-181RESUL } \\
\text { SXL12017-18ISE }\end{array}$ & 1.seq & \\
\hline
\end{tabular}

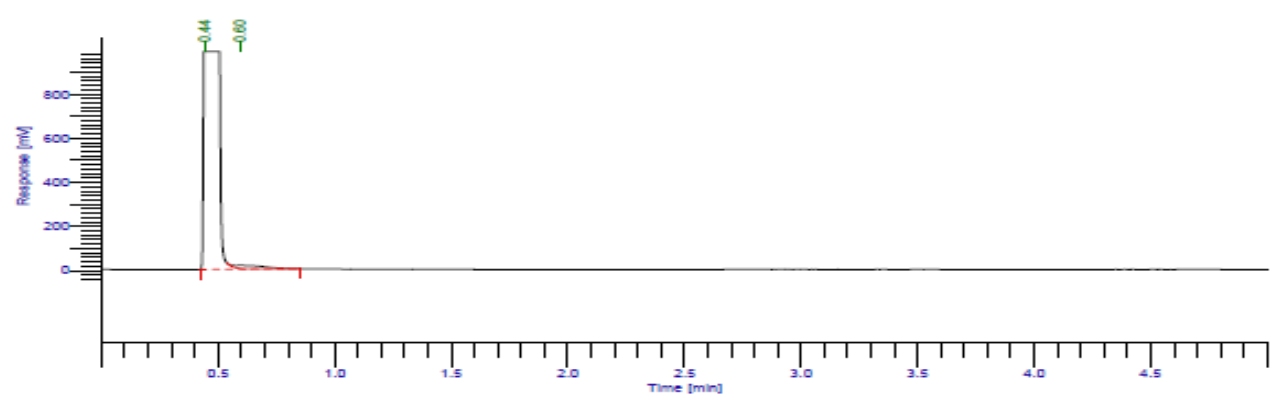

S I C A R T

SHOPHISTICATED INSTRUMENTATION CENTRE FOR APPLIED RESEARCH AND TESTING

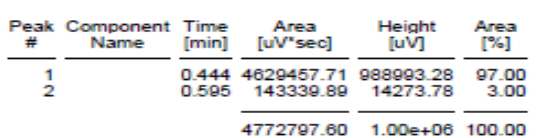

Warning - Signal level out-of-range in peak

SICART-CVM, VALLABH VIDYANGAR- 388120

Fig. 14:-Gas chromatography of Ulva lactuca biogas reactor 


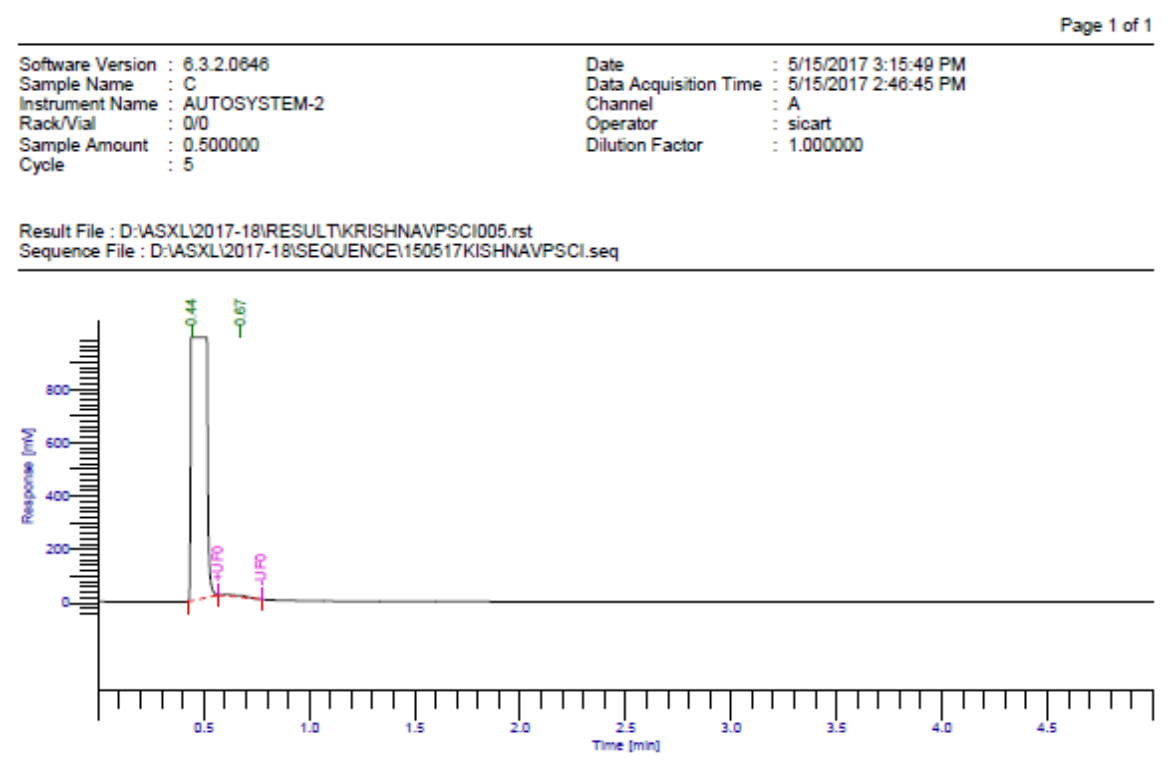

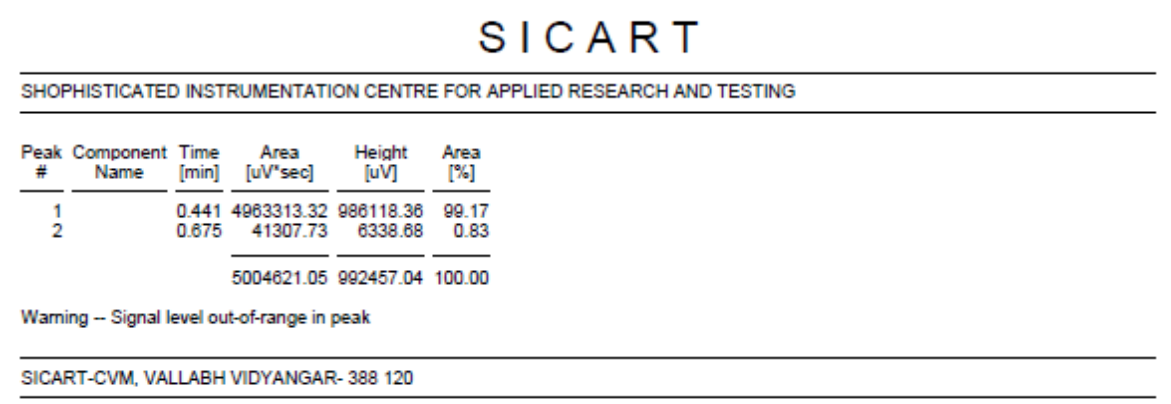

Fig. 15:-Gas chromatography of Kappaphycus alvarezii biogas reactor

\section{Conclusion:-}

In biosorption from effluent shows reduction in metal content such as chromium, nickel and copper. The order of maximum metal reduction was observed in seaweed Kappaphycus alvarezii > Ulva lactuca > Caulerpa racemosa. The equilibrium contact time received 50,60 and 80 minutes for Caulerpa racemosa, Ulva lactuca and Kappaphycus alvarezii respectively. Based on the results of our study it can be concluded that the accumulated seaweed biomass produced from waste water treatment has significant potential for biocompost and biogas yield, in biocompost the values are nearer to specifications of Indian government standards for biocompost which indicates its applicability as biofertilizer. The germination experiment shows significant level of pigment content in plants as compare to control. The biogas yield was observed highest in Caulerpa racemosa > Kappaphycus alvarezii > Ulva lactuca. Thus, the reclamation of accumulated seaweed waste after waste water treatment for the biogas and biocompost generations participates in sustainable environment management as it does not generate secondary waste and turn out to be the source of energy and fertilizer.

\section{Acknowledgement:-}

I am thankful to my co-authorsfor support and guidance and SICART-Vallabhvidyanagar \& BEIL-Ankleshwar for successful completion of the work. 


\section{Reference:-}

1. Agarry S.E., Ogunleye O. O., Ajani O. A. (2015):Biosorptive removal of cadmium (II) ions from aqueous solution by chemically modified onion skin, batch equilibrium, kinetic and thermodynamic studies.Chem EngCommu.,202: 655-673.

2. Angelova R., Baldikova E., Pospikova K., Maderova Z., Safarikova M., Safarik I. (2016): Magnetically modified Sargassumhorneri biomass as an adsorbent for organic dye removal. J of cleaner Prod., 137:189-194.

3. APHA., (1998): Standard Methods for the Examination of Water and Wastewater. 20 ${ }^{\text {th }}$ ed.Washington, DC: American Public Health Association.

4. Aravindhan R., Rao J. R., Nair B. U. (2007): Removal of basic yellow dye from aqueous solution by sorption on green alga Caulerpascalpelliformis. J of Haz Mat. 142: 68-76.

5. Biofertilizers and Organic Fertilizers in Fertilizer Control order, 1985 [Schedule-4, \{Clause 2(h) and (q)\} PartA], National Centre of Organic Farming, Dept of Agriculture and Cooperation, Ministry of Agriculture, New Delhi, Govt of India

6. Brahmbhatt N., Patel R. V., Jasrai R. T. (2012-2013): Accumulation of Chromium by SpirogyraSp, and its effect on its Biochemical Constituents. IntJof Green and Herb Chem.2(1): 15-19.

7. Brahmbhatt N., Patel R. V., Jasrai R. T. (2012-2013): Comparison of Antioxidant Enzymes Activity of Spirogyra Sp and OscillatoriaSp under Heavy Metal Stress. IntJ of Green and Herb Chem.2(1): 1-4.

8. Brahmbhatt N. H., Jasrai R. T., Patel R. V. (2017): Resoluteness of biogas potential of Cr, Pb\& Cd accumulated green algae Spirogyra sp. and Oscillatoriasp. IntJof Bioassay. 6(1): 5224-5229.

9. Brahmbhatt N. H., Jasrai R. T. (2015):Biodecolorization of reactive dyes by Spirogyra sp, Oscillatoriasp. Int J of EngRes and Gen Sci. 3(2): 854-859.

10. Brahmbhatt N. H., Jasrai R. T. (2015):Study the Heavy Metal Accumulated PithophoraAlgal Compost Nutrient Content, Heavy Metals and Biogas Production. Int J of Sci and Res. 4(4):1987-1989.

11. Calicioglu O, Demirer GN. (2016): Biogas production from waste microalgal biomass obtained from nutrient removal of domestic wastewater. Waste Biomass Valorization 7:1397-1408.

12. Davies T. A., Volesky B., and Mucci A. A. (2003): Review of the Biochemistry of Heavy Metal Biosorption by Brown Algae. Water Resources. 37: 4311-4330.

13. Davis T. A., Volesky B., Vieira R. H. S. F. (2000):Sargassum seaweed as biosorbent for heavy metals. Water Resources. 34(17): 4270-4278.

14. Dollhofer V., Podmirseg S. M., Callaghan T. M., Griffith G. W.,Fliegerova K. (2015): Anaerobic Fungi and Their Potential for Biogas Production. AdvBiochemEngBiotechnol. 151:41-61.

15. EPA, (1980): Development document for effluent limitation guidelines and standards for the inorganic chemicals manufacturing point source category, USEPA, Effluent Guidelines Division, Office of Water and Waste Management, Washington, DC.

16. Ghoneim M. M., Desoky H. S., Moselhy K. M., Amer A., Naga E. H. A., Mohamedein L. I., Prol A. E. (2014): Removal of cadmium from aqueous solution using marine green algae, Ulvalactuca. Egyptian J of Aqa Res. 40: 235-242.

17. Hann SD. (1981): Results of municipal waste compost research over more than fifty years at the institute for soil fertility at Haren Groningen the Netherlands. Netherlands J of Agri Sci. 29: 49-61.

18. Hughes A. D., Kelly M. S., Black K. D., Stanley M. S. (2012): Biogas from microalgae. Biotechnol for Biofuels. 5(86): 1-7.

19. Kataria H. C., Gupta M. K., Kushwaha S., Kashyap S., Trivedi S., Bhadoriya R., Bandewar N. K. (2011): Study of physico-chemical parameters of drinking water of Bhopal city with Reference to Health Impacts. Curr World Env. 6(1):95-99.

20. Kousha M., Daneshvar E., Sohrabi M. S., Joker M., Bhatnagar A. (2012): Adsorption of Acid orange 2 dye by raw and chemically modified brown macroalgaeStoechospermummarginatum. ChemengJ, Elsevier science.179:158-168.

21. Latinwo G. K., Jimoda L. A., Agarry S. E., Adeniran J. A. (2015): Biosorption of some heavy metals from Textile Wastewater by Green Seaweed Biomass. UniJofEnv Res and Technol. 5 (4): 210-219.

22. Mendez L., Mahdy A., Ballesteros M., Fernandez G. C. (2015):Chlorella vulgarisvscyanobacterial biomasses, comparison in terms of biomass productivity and biogas yield. EnerConv and Manag. 92: 137-142.

23. Mulbry W., Westhead E., Pizarro C., Sikora L. (2005): Recycling of Manure Nutrients, use of Algal Biomass from Dairy Manure treatment as a slow release fertilizer. Biores Technol. 96: 451-458.

24. Nataraja K. (2008): Feasibility of Using SalviniaMolesta (D. S. Mitchell) for Composting, Vermicomposting and Biogas Generation, Thesis, Department of Agronomy, University of Agricultural Sciences, Dharwad, October. 
25. Pandimurugan R., Thambidurai S. (2016): Synthesis of seaweed-ZnO-PANI hybrid composite for adsorption of methylene blue dye.J of Environ Chem Eng. 4(1):1332-1347.

26. Pandya K. Y., Patel R. V., Jasrai R. T., Brahmbhatt N. (2017):Biodecolorization and Biodegradation of reactive azo dyes by Kappaphycusalvarezii and optimization of biofertilizingpotential.Res J of Recent Sci. 6(6):1-5.

27. Pandya K. Y., Patel R. V., Jasrai R. T., Brahmbhatt N. (2017): Comparison of bioremediation efficiency of Caulerparacemosa, Ulvalactuca from industrial dye effluents. Int J of Rec Sci Res. 8(7):18661-18672.

28. Pandya K. Y., Patel R. V., Jasrai R. T., Brahmbhatt N. H. (2017):Biosorption of Cr, Ni \& Cu from industrial dye effluents onto Kappaphycusalvarezii, assessment of sorption isotherms and kinetics. Int $\mathrm{J}$ of Eng Res and Gen Sci. 5(4): 137-148.

29. Pandya K. Y., Patel R. V., Jasrai R. T., Brahmbhatt N. H. (2017):Optimization of Cr and Cu biosorption by green marine algae Caulerparacemosa Var. Cylindracea\&Ulvalactuca.Int J of AdvRes.5(8):923-939.

30. Pandya K. Y., Patel R. V., Jasrai R. T., Brahmbhatt N. H. (2017): Preliminary Study on Potential of Seaweeds in Decolorization Efficacy of Synthetic Dyes Effluent. Int J of Plant, Animal and Environ Sci. 7(1): 59-69.

31. Pranas B and Misevicius A. (2018):Biogas Production Experimental Research Using Algae.J of Environ Health Sciand Eng. 13: 2015-18.

32. Rathod M., Mody K., Shaik B. (2014): Efficient removal of phosphate from aqueous solutions by red seaweed, Kappaphycusalverezii.J of CleanProd.84(1): 484-493.

33. Salima A., Benaouda B., Noureddine B., Duclaux L. (2013): Application of Ulvalactuca and Systoceirastrictaalgae-based activated carbons to hazardous cationic dyes removal from industrial effluents. Water Res.47 (10): 3375-3388.

34. Sarker S., Bruhn A., Ward A. J., Moller H. B. (2012): Bio-Fuel from Anaerobic Co-Digestion of the MacroAlgae Ulvalactuca, Laminariadigitata, Conference: Renewable energy and energy efficiency. Biogas and biofuel prod technol.86-90.

35. Sode S., Bruhn A., Balsby T. J. S., Larsen M. M., Gotfredsen A., Rasmussen M. B. (2013): Bioremediation of reject water from anaerobically digested waste water sludge with microalgae, Ulvalactuca, Chlorophyta. Biores Technol. 146: 426-435.

36. Subasi E. D., Demirer G. N., Demirer S. U. (2017): Biogas and Bio fertilizer production by anaerobic digestion of Chlorella Vulgaris, ISER International Conference, Chicago, USA.1-5.

37. Subasi E. D., Demirer G. N. (2016): Anaerobic digestion of microalgal (Chlorella vulgaris) biomass as a source of biogas and biofertilizer. Environ Progress \& Sustain Energy. 35:936-941.

38. The Environment (Protection) Rules, 1986 [schedule - vi] (see rule 3a), General Standards for Discharge of Environmental Pollutants Part-A: Effluents

39. Thimmaiah S. K. (2014): Standard Methods of Biochemical Analysis, Kalyani Publishers, India. p. 545.

40. Xun Y., Shu-Ping Z., Wei Z., Hong-you C., Xiao-Dong D., Xin-Mei L., Zi-Feng Y. (2007): Aqueous dye adsorption on ordered malodorous carbons. J of CollInterf Sci. 310: 83-89.

41. Yen H. W., Brune D. E. (2007): Anaerobic co-digestion of algal sludge and waste paper to produce methane. Biores Technol. 98: 130-134.

42. Zupancic GD, Panjičko M, Zelić B. Biogas Production from Brewer's Yeast Using an Anaerobic Sequencing Batch Reactor. Food Technology and Biotechnology 2017; 55(2):187-196. 